\title{
Myocardial protection by continuous, blood, antegrade-retrograde cardioplegia in rabbits ${ }^{1}$
}

\author{
Proteção miocárdica da cardioplegia sanguínea contínua, \\ anterógrada e retrógrada em coelhos
}

\author{
Antônio Sérgio Martins², Marcos Augusto de Moraes Silva ${ }^{3}$, Carlos Roberto Padovani ${ }^{4}$, Beatriz Boljokian Matsubara ${ }^{5}$, \\ Domingo Marcolino Braile ${ }^{6}$, Antonio José Maria Catâneo ${ }^{7}$ \\ 1. Research performed at Surgical Research Laboratory, Botucatu Faculty of Medicine, State University of São Paulo (UNESP), Brazil. \\ 2. Assistent Professor, Surgery Department, UNESP, Botucatu, Brazil. \\ 3. Assistant Professor, Surgery Department, UNESP, Botucatu, Brazil. \\ 4. PhD, Full Professor of Mathematics and Statistical Department, UNESP, Botucatu, Brazil. \\ 5. PhD, Full Professor, Cardiology Department, UNESP, Botucatu, Brazil. \\ 6. PhD, Full Professor, Surgery Department, Faculty of Medicine (FAMERP), São Jose do Rio Preto, Brazil. \\ 7. PhD, Full Professor, Surgery Department, UNESP, Botucatu, Brazil.
}

\begin{abstract}
Purpose: To study the effectiveness of the continuous, blood, antegrade-retrograde cardioplegia in an experimental model of isolated heart, evaluating ventricular function. Methods: Rabbits were divided into four groups: Control-C(n=10); ischemic crystalloid cardioplegia-IC $(n=10)$; ischemic blood cardioplegia-IB $(n=10)$; ischemic non cardioplegia-INC $(n=10)$. After the ischemic protocol period the ventricular function was analyzed by the intra-ventricular balloon technique. Results: the intra-ventricular developed pressure (IVDP) was: C(92.90 $\pm 6.86 \mathrm{mmHg})$; IC $(77.78 \pm 6.15 \mathrm{mmHg})$; $\mathrm{IB}(93.64 \pm 5.09 \mathrm{mmHg}) ; \mathrm{INC}(39.46 \pm 8.91 \mathrm{mmHg}) \mathrm{p}<0.005$. The first derivative of intra-ventricular pressure in its positive deflection was: $\mathrm{C}(1137.50 \pm 92.23 \mathrm{mmHg} / \mathrm{sec}) ; \mathrm{IC}(1130.62 \pm 43.78 \mathrm{mmHg} / \mathrm{sec}) ; \mathrm{IB}(1187.58 \pm 88.38 \mathrm{mmHg} / \mathrm{sec}) ; \mathrm{INC}(620.02 \pm$ $43.80 \mathrm{mmHg} / \mathrm{se}) \mathrm{p}<0.005$. The first derivate pressure in its negative deflection was: $\mathrm{C}(770.00 \pm 73.41 \mathrm{mmHg} / \mathrm{sec}) ; \mathrm{IC}(610.03$ $\pm 47.43 \mathrm{mmg} / \mathrm{sec}) ; \mathrm{IB}(762.53 \pm 46.02 \mathrm{mmHg} / \mathrm{sec}) ; \mathrm{INC}(412.35 \pm 84.36 \mathrm{mmHg} / \mathrm{sec}) \mathrm{p}<0,005$. The stress-strain angular logarithmic coefficient was: $\mathrm{C}(0.108 \pm 0.02) ; \operatorname{IC}(0.159 \pm 0.038) ; \operatorname{IB}(0.114 \pm 0.016) ; \operatorname{INC}(0.175 \pm 0.038) \mathrm{p}<0.05$. Conclusion: The ischemic group protected by blood cardioplegia showed better ventricular function than ischemic group protected by crystalloid cardioplegia and the non protected group.
\end{abstract}

Key words: Ventricular Function. Ischemia. Myocardium. Animal, Models. Heart Arrest, Induced. Rabbits.

\section{RESUMO}

Objetivo: Estudar a eficácia e a segurança da cardioplegia sanguínea, aterógrada-retrógrada contínua, por meio da avaliação da função ventricular. Métodos: Os coelhos foram divididos em quatro grupos: Controle- $\mathrm{C}(\mathrm{n}=10)$; isquêmico e cardioplegia cristaloide- $\mathrm{IC}(\mathrm{n}=10$; isquêmico e cardioplegia sanguínea- $\mathrm{IB}(\mathrm{n}=10$; isquêmico sem cardioplegia-INC( $\mathrm{n}=10$. Após o período isquêmico do protocolo a função ventricular foi analisada pela técnica do balão intra-ventricular. Resultados: a pressão

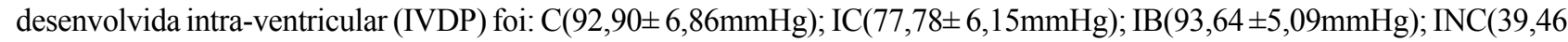
$\pm 8,91 \mathrm{mmHg}) \mathrm{p}<0,005$. a primeira derivada temporal da pressão ventricular na sua deflexão positiva: $\mathrm{C}(1137,50 \pm 92,23 \mathrm{mmHg} /$ sec); IC(1130,62 $\pm 43,78 \mathrm{mmHg} / \mathrm{sec}) ; \operatorname{IB}(1187,58 \pm 88,38 \mathrm{mmHg} / \mathrm{sec}) ; \operatorname{INC}(620,02 \pm 43,80 \mathrm{mmHg} / \mathrm{se}) \mathrm{p}<0,005$. A primeira derivada da pressão ventricular na sua deflexão negativa: $\mathrm{C}(770,00 \pm 73,41 \mathrm{mmHg} / \mathrm{sec}) ; \mathrm{IC}(610,03 \pm 47,43 \mathrm{mmg} / \mathrm{sec}) ; \mathrm{IB}(762,53$ $\pm 46,02 \mathrm{mmHg} / \mathrm{sec}) ; \mathrm{INC}(412,35 \pm 84,36 \mathrm{mmHg} / \mathrm{sec}) \mathrm{p}<0,005$. A relação do coeficiente angular logarítmico foi: $\mathrm{C}(0,108 \pm 0,02)$; $\operatorname{IC}(0,159 \pm 0,038) ; \operatorname{IB}(0,114 \pm 0,016) ; \operatorname{INC}(0,175 \pm 0,038) \mathrm{p}<0,05$. Conclusão: No modelo experimental estudado o grupo isquêmico protegido pela cardioplegia sanguínea apresentou melhor função ventricular que os grupos protegidos por cardioplegia cristalóide e não protegido.

Descritores: Função Ventricular. Isquemia. Miocárdio. Modelos Animais. Parada Cardíaca Induzida. Coelhos.

\section{Introduction}

The results of contemporary coronary artery bypass graft surgery (CABG) are exceptional. However, recently changing trends in the population at risk have resulted in increasing numbers of high-risk eligible patients for $\mathrm{CABG}$, with an accompanying rise in postoperative morbidity including low output syndrome(LOS) ${ }^{1}$.Many techniques have been proposed for myocardial protection, but the results are very difficult to be interpreted. Many authors reported their techniques applied to human beings. The difference among the populations, technique variations, 
different surgeons and the absence of large random studies makes the results interpretation a "magic" task. The experimental models not only allow a controlled environment but they are necessary before used in human beings. At the first moment in the history of cardiac surgery the aortic-cross clamping was the unique technique for myocardial protection ${ }^{2}$, but the mortality rate was prohibitive. Gerbode and Melrose ${ }^{3}$ innovated with the cardiac arrest induced by a potassium solution, despite his controversial result. Hearse ${ }^{4}$, at St Thomas Hospital, studied the crystalloid cardioplegic solution, first in animals and after in human beings, bringing us a new revolution. But specific sub-groups of patients, particularly the ones with depressed left ventricular function and important ventricular hypertrophy remains with elevated mortality rates. Braile ${ }^{5}$ studied and standardized the blood cardioplegia. Many other authors proposed many variations of this myocardial protection technique with encouraging results. Our purpose was to study the Braile's myocardial protection technique effectiveness in the myocardial preservation when a long period of ischemia was applied in an experimental model.

\section{Methods}

Rabbtis (California-2000) $(n=40)$ of both sex were used in the isolated heart model as described by Martins et al. ${ }^{6}$ After a 20-minute stabilization the isolated hearts were divided into four groups: control group-C-group without ischemia e perfused at 120 minutes. IC-group submitted at 120 minutes of cardiac arrest induced and protected by cardioplegic solution (St Thoma's). IB-group submitted at 120 minutes of cardiac arrest and protected by blood continuous antegrade e retrograde cardioplegia. NC-group submitted at 120 minutes of ischemia with cardiac arrest by natural depletion of its energy subtracts with no protective method.

\section{Protocol}

To the control group-C: perfusion with constant pressure $(70 \mathrm{mmHg})$ for 120 minutes, after this a pacemaker was inserted in the right ventricle (120 eps) and a balloon in the left ventricle for contractile parameters evaluation. To the other groups after the same period of a 20 minutes stabilization, a 120-minute period of cardiac arrest was induced by cardiologic solution with crystalloid (IC group) and blood (IB group). To NC group no protective method was used. After another 20-minute stabilization period a pacemaker was inserted in the right ventricle (120 eps) and a balloon in the left ventricle for contractile parameters evaluation.

\section{Cardioplegic solutions}

Crystalloid-St Thoma's

Blood-produced by Braile Biomedica ${ }^{\circledR}$

\section{Statistical analysis}

Statistical analysis was performed by variance analysis complemented by Tukey test. A probability of $\mathrm{p}<0.05$ was considered to be statistically significant. The results were expressed as mean \pm SEM.

\section{Evaluation of contractile parameters}

The balloon technique as described by Matsubara et al. ${ }^{7}$

The stress- strain relation as the formula reported by Jail et al. ${ }^{8}$

\section{Ethical consideration}

This study was analyzed and approved by the local Ethical Committee of Animal Experimentation-School of Medicine of Botucatu-UNESP.

\section{Results}

Intra-ventricular developed pressure(IVDP):

The IB group showed the best results comparable to the Control group ones. There was significant difference between the IB and IC and between both and NC group (figure1).

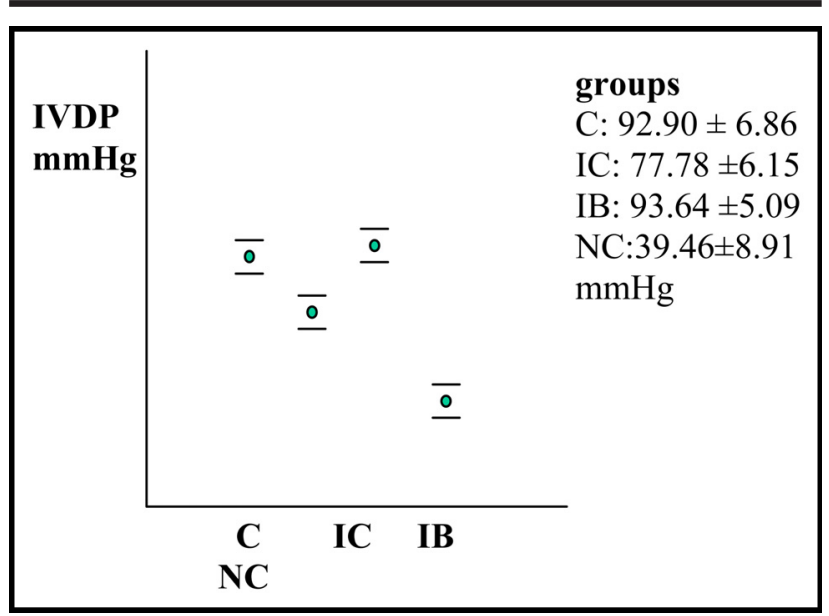

FIGURE 1 - Graphic representation of IVDP (Intraventricular Developed Pressure) and groupsC-control; ICischemic crcrystalloid; IB-ischemic Blood; NCischemic non proteted.

The first derivative of intra-ventricular pressure in its positive deflection $(\mathrm{dp} / \mathrm{dt}+)$ :

IB, IC and control groups showed similar results with no significant difference among them, but they were significantly different from NC group (figure 2).

The first derivative of intra-ventricular pressure in its negative deflection (dp/dt-):

The IB group showed the best results comparable to the Control group ones. There was significant difference between the IB and IC and between both and NC group (figure 3). 


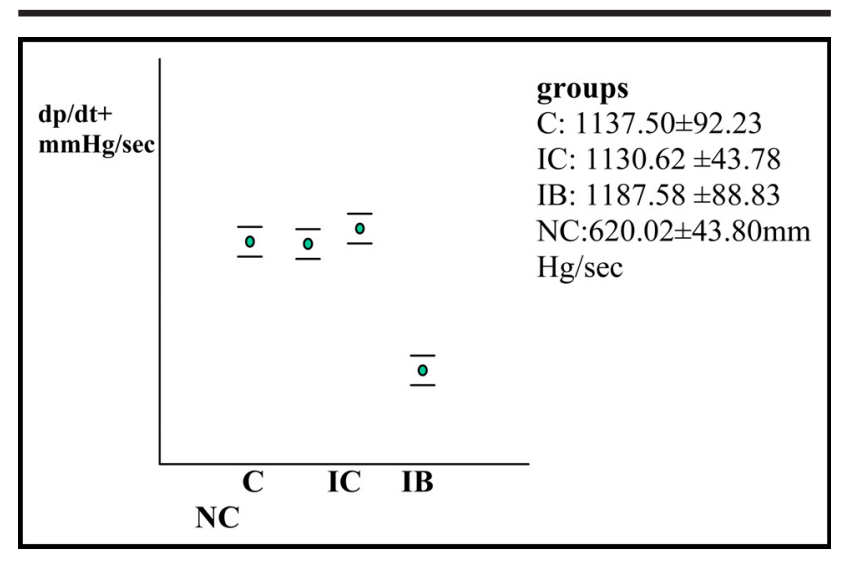

FIGURE 2 - Graphic representation of $\mathrm{dp} / \mathrm{dt}+$ (first derivative pressure in its positive deflection) and groups Ccontrol; IC-ischemic crystalloid; IB-ischemic Blood; NCischemic non proteted.

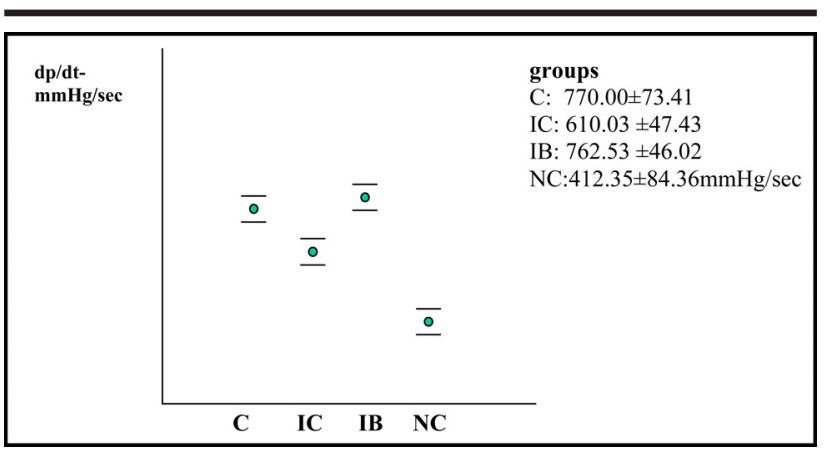

FIGURE 3 - Graphic representation of dp/dt-(first derivative pressure in its negative deflection) and groups C-control; IC-ischemic crystalloid; IB-ischemic Blood ; NC-ischemic non proteted

\section{The stress-strain angular logarithmic coefficient:}

The IB group showed the best results. There was no significant difference between IC and NC groups (figure 4).

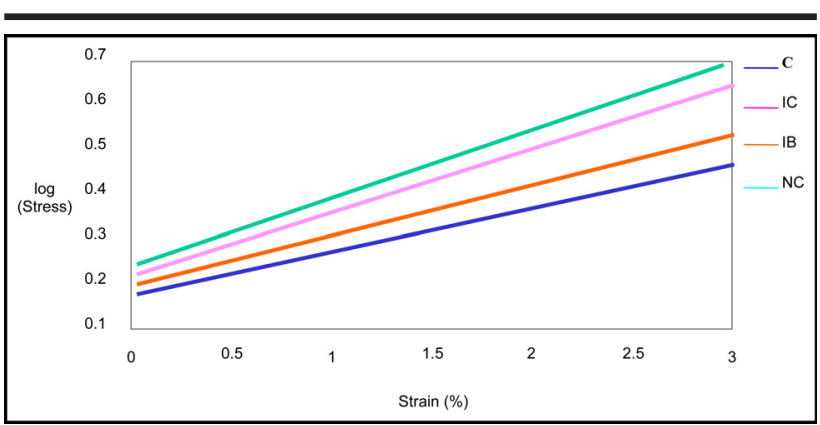

FIGURE 4 - Graphic representation of log/stress-strain an groups

\section{Discussion}

For the evaluation of the ventricular function, the intraventricular balloon method was used as described and consecrated in the literature. Goto et al. ${ }^{9}$ tested the effectiveness of the method by reflecting the exact intraventricular volume, evaluating the residual space. This varied from 1.5 to $3.6 \%$ for pressures between 40 and $160 \mathrm{mmHg}$ and it was $14.6 \%$ for inferior pressures at $5 \mathrm{mmHg}$, confirming the reliability of the method. There are, in the literature, established relationships between animal and heart weight. The frequency and the rhythm influence the contractile state of the myocardium ${ }^{10}$. This action, known as Bowdicht effect, settles down at the level of the membrane of the miocardic cell. With the increase of frequency sodium ions enter inside the cellular membrane, what contributes to the elevation of intracellular calcium concentration ${ }^{11}$. To avoid this problem we opted for establishing fixed frequency of $150 \mathrm{epm}$. The use of blood solution presents advantages, as, for example, close flows to the physiologic status, better oxygen distribution and smaller edema after perfusion period. The IVDP and the $\mathrm{dp} / \mathrm{dt}+$ are parameters commonly used to analyze the systolic function. At first sight, the results must be considered contradictory but we should consider that $\mathrm{dp} / \mathrm{dt}+$ is a limited index, because it suffers several influences, such as: after-load, pre-load, heart inotropism and variation of the diastolic pressure ${ }^{12}$ . The IVDP is obtained by the constant difference between the systolic and diastolic pressure and for this model is considered a powerful parameter. The dp/dt- is an index very used for analysis of the diastolic ventricular function, especially in its active phase. To myocardial relaxation it is necessary that the citosolic calcium be actively kidnapped inside the sarcoplasmatic reticulum or removed from the cell ${ }^{13}$. This is an active process, accomplished by the action of an enzyme ATPase, magnesium dependent. Another path to remove the calcium íons is the change with sodium íons in the cellular via. During ischemic periods, there is reduction of the ATP levels, damaging the active process of calcium retreat. The diastolic stress is defined as a force applied to a muscular area capable to stretch it. The strain is defined as the percentage of deformation of a cavity starting from an initial dimension, when a deformant force is applied ${ }^{14}$. The diastolic stress/strain relationship contemplates, therefore, the muscle rigidity. The stress/ strain relationship is not a linear but an exponential function, meaning that the myocardium distensability is progressively smaller as it is stretched. The IB group showed results similar to control group and significantly better than IC and NC group. It means that blood cardioplegia was capable to protect the isolated heart from ischemic damage but the crystalloid cardioplegia was not. These results are coherent with the clinical reports in the literature ${ }^{15}$.Although it is difficult to demonstrate differences among the several techniques of myocardial protection concerning mortality rate, in general it is consent that the sanguine cardioplegia brings better myocardial protection to specific groups of patients such as left ventricular depressed and important hypertrophy. In this experimental model we used the long time of aortic-cross clamping as an aggravating factor. The most important critic is that the hearts continue being normal. A model that uses an abnormal heart was reported by our team and is now being studied. 


\section{Conclusion}

In this experimental model, concerning the applied protocol, we demonstrated the effectiveness of blood cardioplegia in myocardial protection after acute period of ischemia.

\section{References}

1. Jha AK, Epstein AM. The predictive accuracy of the New York State coronary artery bypass surgery reportcard system. Health Aff. 2006; 25: 844-55.

2. Braile DM, Godoy F. The history of cardiac surgery. Arq Bras Cardiol. 1996; 66: 329-37.

3. Gerbode F, Melrose D. The use of potassium arrest in open cardiac surgery. Am J Surg. 1958; 96: 221-7.

4. Hearse DJ. Myocardial protection during ischemia and reperfusion. Mol Cell Biochem. 1998; 186: 177-84.

5. Braile D. Advantages of assisted circulation. Arq Bras Cardiol. 1990; 55: 146-7

6. Martins AS, Silva MAM, Matsubara BB, Aragon F, Padovani, CR. Standardization of an experimental model of parabiotic isolated heart in rabbits. Acta Cir Bras. 2000; 15: 156-62.

7. Matsubara LS, Paiva SA, Narikawa S, Zornoff L, Matsubara BB. Myocardial remodeling in chronic pressure or volume overload in the rat heart. Arq Bras Cardiol. 2006; 86: 126-30.
8. Jalil JE, Doering CW, Janick JS, Pick R, Shroof SG, Weber KT. Fibrillar collagen and myocardial stiffness in the intact hypertrophied rat left ventricle. Circ Res. 1989; 64: 1041-50.

9. Goto Y, Slinker BK, LeWinter KT. Accuracy of volume measurement of rabbit left ventricle by balloon method. Am J Physiol. 1988; 255 (2 Pt 2): H394-6.

10. Okoshi K, Fioretto JR, Bonatto RC, Tornero MTT, Tucci PJF. Influence of the elevation of the left ventricular diastolic pressure on the values of the first temporal derivative of the ventricular pressure $(\mathrm{dP} / \mathrm{dt})$. Arq Bras Cardiol. 1999; 73: 37-46.

11. Lakatta V. Beyond Bowditch: the convergence of cardiac chronotropy and inotropy. Cell Calcium. 2004; 35: 629-42.

12. Buckberg GD, Castellá M, Gharib M, Saleh S. Active myocyte shortening during the 'isovolumetric relaxation' phase of diastole is responsible for ventricular suction; 'systolic ventricular filling'. Eur J Cardiothorac Surg. 2006; 29S1: S98-S106..

13. Nayler WG, Willians A. Relaxation in heart muscle: some morphological and biochemical considerations. Eur J Cardiol. 1978; 7 (Suppl): 35-50.

14. Hoshijima M. Mechanical stress-strain sensors embedded in cardiac cytoskeleton: $Z$ disk, titin, and associated structures. Am J Physiol Heart Circ Physiol. 2006; 290: H1313-25.

15. Sirvinskas E, Nasvyts L, Raliene L, Vaskelyte J, Toleikis A, Trumbeikate S. Myocardial protective effect of warm blood, tepid blood, and cold crystalloid cardioplegia in coronary artery bypass grafting surgery. Croat Med J. 2005; 46: 879-88.

\section{Correspondence:}

Antônio Sergio Martins

Departamento de Cirurgia e Ortopedia

Faculdade de Medicina

Universidade Estadual Paulista

Distrito de Rubião Junior, s/n.

18.618-000 - Botucatu - SP- Brasil

Phone: (14) 3811-6230

Fax:(14) 3815-7615

e-mail: asmartinsbtu@uol.com.br
Conflict of interest: none Financial source: none

\section{How to cite this article:}

Martins AS, Silva MAM, Padovani CR, Matsubara BB, Braile DM, Catâneo AJM. Myocardial protection by continuous, blood,antegrade-retrograde cardioplegia in rabbits. Acta Cir Bras. [serial on the Internet] 2007 Jan-Feb;22(1). Available from URL: http://www.scielo.br/acb. 